\title{
Effects of polymorphisms in ovine and caprine prion protein alleles on cell-free conversion
}

\author{
Martin Eiden ${ }^{1}$, Elizabeth Ortega Soto ${ }^{1}$, Thomas C Mettenleiter², Martin H Groschup 1*
}

\begin{abstract}
In sheep polymorphisms of the prion gene (PRNP) at the codons 136, 154 and 171 strongly influence the susceptibility to scrapie and bovine spongiform encephalopathy (BSE) infections. In goats a number of other gene polymorphisms were found which are suspected to trigger similar effects. However, no strong correlation between polymorphisms and TSE susceptibility in goats has yet been obtained from epidemiological studies and only a low number of experimental challenge data are available at present. We have therefore studied the potential impact of these polymorphisms in vitro by cell-free conversion assays using mouse scrapie strain Me7. Mouse scrapie brain derived $\operatorname{PrPSC}^{\mathrm{Sc}}$ served as seeds and eleven recombinant single mutation variants of sheep and goat $\operatorname{PrP}^{C}$ as conversion targets. With this approach it was possible to assign reduced conversion efficiencies to specific polymorphisms, which are associated to low frequency in scrapie-affected goats or found only in healthy animals. Moreover, we could demonstrate a dominant-negative inhibition of prion polymorphisms associated with high susceptibility by alleles linked to low susceptibility in vitro.
\end{abstract}

\section{Introduction}

Prion diseases include scrapie in sheep, bovine spongiform encephalopathy (BSE) in cattle and CreutzfeldtJacob-Disease (CJD) in humans and are characterized by the conversion of cellular prion protein $\left(\operatorname{PrP}^{C}\right)$ into an abnormal pathological isoform called $\mathrm{PrP}^{\mathrm{Sc}}$. In the course of the conversion the prion protein is transformed from a predominantly $\alpha$-helical structure into a $\beta$-sheet rich conformation. Disease development is characterized by an accumulation of $\operatorname{PrP}^{\mathrm{Sc}}$ followed by neuronal degeneration and CNS dysfunction. The PrP gene (PRNP) polymorphisms have been associated with distinct disease phenotypes in humans and sheep. These phenotypes include differences in the incubation period, $\operatorname{Pr} \mathrm{P}^{\mathrm{Sc}}$ deposition pattern, pathogenesis and even clinical signs following the infection with a given strain or isolate. Sheep carrying the PRNP polymorphisms valine (V) or alanine (A) at codon 136 (136V and 136A) are highly susceptible to classical scrapie, while the exchange of arginine $(\mathrm{R})$ to histidine at codon $154(154 \mathrm{H})$ is linked to low scrapie susceptibility $[1,2]$. Interestingly, this allele is

\footnotetext{
* Correspondence: martin.groschup@fli.bund.de

${ }^{1}$ Institute for Novel and Emerging Infectious Diseases at the FriedrichLoeffler-Institut, Federal Research Institute for Animal Health, D-17493

Greifswald-Insel Riems, Germany

Full list of author information is available at the end of the article
}

associated with high susceptibility to atypical/Nor98 scrapie in sheep and goats $[3,4]$ and short incubation periods in BSE infected sheep [5]. The exchange of glutamine (Q) to arginine $(\mathrm{R})$ at codon 171 (171R) induces a nearly resistant phenotype [6,7]. Based on these findings a sheep breeding program in Europe was carried out to propagate the 171R allele [8].

Genetic analysis of the goat PRNP revealed 42 polymorphisms in the open reading frame including silent mutations [9]. Some of these polymorphisms are associated with changes in the susceptibility to scrapie: At codon 142 an exchange from isoleucine (I) to methionine (M) $(142 \mathrm{M})$ prolongs the incubation time after a challenge with scrapie and BSE prions [10]. A reduced susceptibility to natural scrapie has also been reported for goats carrying arginine (R) at codon 143 (143R) and histidine $(\mathrm{H})$ at codon $154(154 \mathrm{H})$ [11] in the PRNP gene as well as for goats with glutamine (Q) at codon 211 (211Q) [12]. Recently, two novel polymorphism were found at position 146, harboring serine (S) or aspartic acid (D) (146S, 146D), which were linked to resistance against scrapie [13]. In addition, lysine (K) at codon 222 (222K) is only found in healthy goats and is associated with low susceptibility to scrapie [14]. The caprine wildtype allele contained isoleucin (I) at position 142, histidine $(\mathrm{H})$ at position 143 , asparagine $(\mathrm{N})$ at position 146 , arginine $(\mathrm{R})$
C Biomed Central

() 2011 Eiden et al; licensee BioMed Central Ltd. This is an Open Access article distributed under the terms of the Creative Commons Attribution License (http://creativecommons.org/licenses/by/2.0), which permits unrestricted use, distribution, and reproduction in any medium, provided the original work is properly cited. 
at positions 151 and 211 and glutamine $(\mathrm{Q})$ at position 222 and was subsequently denoted IHNRRQ. Because of the variety of mutations in the caprine PRNP gene, their impact on the susceptibility is difficult to ascertain experimentally in vivo.

To analyze the effect of single amino acid substitutions on the convertibility of ovine and caprine prion protein variants, an in vitro approach was therefore used in this study. Several in-vitro assays were reported before. The first assay that was reported used purified and radiolabeled $\operatorname{PrP}^{\mathrm{C}}$ molecules, which were incubated with $\mathrm{PrP}^{\mathrm{Sc}}$ seeds and converted into proteinase $\mathrm{K}$ resistant $\operatorname{Pr} \mathrm{P}^{\text {res }}$ fragments [15-17]. This type of assay was intensively used to analyze interspecies and intraspecies transmission barriers [18]. Recently, a modified cell-free conversion assay was established which uses both prion components under equimolar and semi-native conditions [19]. Another assay was published which dealt with aggregation and fibrillation of recombinant prion protein in the absence of $\operatorname{PrP}^{\mathrm{Sc}}$ seeds [20]. However, the infectious nature of the so-called "synthetic prions" still remains enigmatic [21].

In this study we used a cell-free conversion assay to evaluate PRNP polymorphisms in sheep and goats in vitro. We therefore generated 11 bacterial prion variants haboring different ovine and caprine $\operatorname{PrP}^{\mathrm{C}}$ polymorphisms. The conversion was carried out with mouse passaged scrapie strain Me7, which originated from classical scrapie isolates [22]. Our results provide important clues regarding impacts of aminoacid exchange on the conversion of prion protein and demonstrate a high accordance between our findings in vitro and epidemiological data.

\section{Material and methods Mutation of PRNP}

Ovine prion alleles were amplified from the ORF 23-234 by PCR using primers ov1 (5'-CCGGATCCAAGAAGCGACC AAAACC-3') and ov2 (5'-CCAAGCTTCTAG CTGGATC TTCTCCCG-3'). As template we used genomic DNA from genotyped homozygous sheep alleles (136A, 154H and 171R) [23]. Caprine polymorphisms were generated by the substitu-tion of amino acids at residues 142, 143, 146, 151, 211 and 222 using the ovine 136A allele as a template. The caprine mutations were carried out by a two step PCR which first uses internal primers for the particular substitution and then external primers ov1/ov2 for the amplification of the mutant template. The $142 \mathrm{M}$ mutation was introduced by the use of a forward primer (forv) 5'-AGG CCT CTT ATG CAT TTT GGC-3' and a reverse primer (rev) 5'-GCC AAA ATG CAT AAG AGG CCT-3', the 143R mutation with forv 5'-CCT CTT ATA CGT TTT GGC AAT G-3' and rev 5'-C AAT GCC AAA ACG TAT AAG AGG-3' primer, the $146 \mathrm{~S}$ with forv 5'-CAT TTT GGC TCT GAC TAT GAG-3' and rev
5'-CTC ATA GTC AGA GCC AAA ATG-3' primer, the 146D with forv 5'-CAT TTT GGC GAT GAC TAT GAG-3' and rev 5'-CTC ATA GTC ATC GCC AAA ATG-3' primer, the $151 \mathrm{H}$ mutation with forv 5'-C TAT GAG GAC CAT TAC TAT CG-3' and rev 5'-CG ATA GTA ATG GTC CTC ATA G-3' primer, 211Q with forv 5'-GATA ATG GAG CAA GTG GTG GAG-3' and rev 5'-CTC CAC CAC TTG CTC CAT TAT C-3' primer and the $222 \mathrm{~K}$ mutation with rev 5'-GG AAC CTT CTA ACT TGC CCC CCT TTG GTA ATA AGC CTG GGA TTC TCT CTT GTA CTG G-3’ primer.

\section{Expression and purification of recombinant PrP}

The amplified gene was cloned via BamHI and HindIII restriction sites into the vector pQE-40 (Qiagen, Hilden, Germany) which harbors an N-terminal histidin (his-)-tag. Expression and purification was described previously [19]. In brief, purification was carried out under denaturating conditions over an N-terminal His-tag using a Ni-NTAcolumn according to standard procedures. Refolding was accomplished by dialysis in the corresponding refolding buffer [24]. CD spectra of all constructs displayed a high content of $\alpha$-helical structure, which indicates proper folding of the proteins (data not shown).

\section{Cell-free conversion assay}

Cell-free conversion was carried out by mixing $400 \mathrm{ng}$ of recombinant prion protein with $400 \mathrm{ng}$ purified $\mathrm{PrP}^{\mathrm{Sc}}$ seeds (mouse passaged scrapie strain Me7) in a modified conversion buffer (50 mM citrate $\mathrm{pH} 6.0,200 \mathrm{mM} \mathrm{KCl}$, $5 \mathrm{mM} \mathrm{MgCl}_{2}, 1.25 \% \mathrm{~N}$-lauroylsarcosine and $2.0 \mu \mathrm{g} / \mu \mathrm{L}$ suramine). After three days of incubation at $37^{\circ} \mathrm{C}$ the samples were treated with Proteinase K (PK) for $1 \mathrm{~h}$ at $37^{\circ} \mathrm{C}$ at a final concentration of $30 \mu / \mathrm{mL}$ (in $50 \mathrm{mM}$ Tris/ $\mathrm{HCl}, \mathrm{pH} 7.4,150 \mathrm{mM} \mathrm{NaCl}$ ). The reaction was stopped with $10 \mathrm{mM}$ Phenylmethylsulfonylfluorid (PMSF). Thyreoglobuline was added to the samples, which were subsequently incubated in methanol at $-20{ }^{\circ} \mathrm{C}$ for at least $1 \mathrm{~h}$ [19]. Proteins were pelleted by centrifugation at 13000 rounds per minute (rpm) for $15 \mathrm{~min}$ and subjected to sodium dodecyl sulphate-polyacrylamide gel electrophoresis (SDS-PAGE). $\mathrm{PrP}^{\mathrm{Sc}}$ was purified from terminally scrapie diseased mouse brains (mouse scrapie Me7) according to a previous publication [19]. Detection of the newly converted $\operatorname{PrP}^{\text {res }}$ fragments was accomplished by immunoblotting, using mab P4 [25] as detection antibody and a chemiluminiscence visualisation. Chemiluminescence signals were detected using the BioRad VersaDoc ${ }^{\mathrm{TM}}$ photo imaging system and analysed with the Quantity One quantification software (BioRad, Munich, Germany). All constructs were analysed in a cell-free conversion assay and the conversion rates of $\operatorname{PrP}$ variants were calculated on the basis of the generated $\operatorname{PrP}^{\text {res }}$ fragments. Relative conversion rates of ovine $\operatorname{PrP}$ variants were calculated in relation 
to the ovine 136A reference allele $(n=4)$ and the goat derived variants in relation to the caprine IHNRRQ reference allele $(n=8)$. Statistical analysis was performed with unpaired student $t$-test and statistical significance was expressed as follows: ns: not significant, ${ }^{*}: p<0.05,{ }^{* * *}: p<$ $0.01,{ }^{* * * * *}: p<0.001$. In the case of unequal statistical spread of variances, Student's $t$-test was supplemented by the Welch correction (Welch's $t$-test).

\section{Results}

Figure 1 shows the conversion of recombinant prokaryotic ovine prion protein (136A allele) into its PK resistant form, $\operatorname{PrP}^{\text {res }}$ (Figure 1A, lane 2). The shift of approximately $6-7 \mathrm{kDa}$ (in comparison to the nontreated control) (Figure 1A, lane 1) results from the partial resistance of $\operatorname{PrP}^{\text {res }}$, i.e. removal of the nonstructured $\mathrm{N}$-terminus. The relative ratio of converted $\mathrm{PrP}^{\mathrm{C}}$ was approx. $5 \%$ of the $\operatorname{PrP}^{C}$ that was initially used in the reaction. Conversions were carried out with mouse passaged scrapie strain Me7 as described before [19]. The physiological relevance of the assay was demonstrated with ovine PrP polymorphisms $154 \mathrm{H}$ and $171 \mathrm{R}$, which strongly affect the scrapie susceptibility in sheep. In vitro, the conversion of the $154 \mathrm{H}$ (Figure 1A, lane 3) and 171R alleles were almost completely absent (Figure 1A, lane 4) compared to 136A conveying susceptibility in vivo (Figure $1 \mathrm{~A}$, lane 2). The relative conversion rates were $1.9 \%$ and $2.14 \%$ respectively as shown in Figure 1B.

To examine, whether the alleles $154 \mathrm{H}$ or $171 \mathrm{R}$, which are linked to low susceptibility, had an inhibitory effect on the cell-free conversion of the ovine 136A allele, 1:1 mixtures of $136 \mathrm{~A}$ with variants $154 \mathrm{H}$ or $171 \mathrm{R}$ (corresponding to heterozygous $136 \mathrm{~A} / 154 \mathrm{H}$ and $136 \mathrm{~A} / 171 \mathrm{R}$ animals) were carried out. Both combinations 136A/ 171R (Figure 2A, lanes 4-5) and 136A/154H (Figure 2A, lanes 6-7) showed a clear reduction to $17.5 \%(154 \mathrm{H})$ and $12.3 \%(171 \mathrm{R})$ in the conversion rates (Figure 2B) compared to 136A alone (Figure 2A, lane 1, Figure 2B). As a control a 1:1 mixture of $136 \mathrm{~A}$ with bovine serum albumine as additive was used (retaining the same total amount of protein of the sample) in order to analyse the conversion rate of $50 \%$ of the original $136 \mathrm{~A}$ PrP. The determined reduction was $59 \%$, which correlates to the half of the amount of 136A (Figure 2A, lanes 2-3, Figure $2 \mathrm{~B})$. The significant reduction by $154 \mathrm{H}$ and $171 \mathrm{R}$ allele, which exceeded $50 \%$ by far, underlines their direct

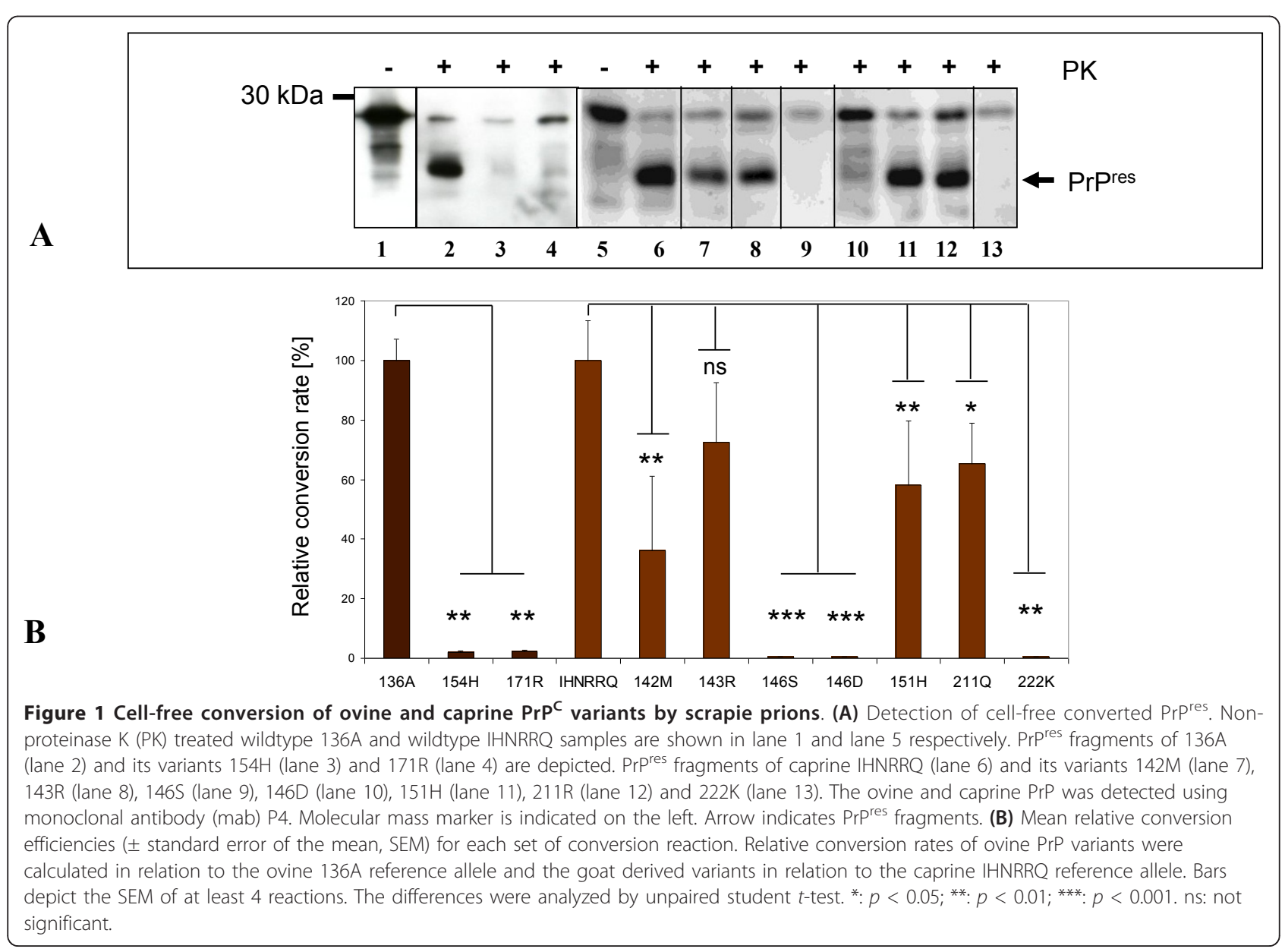



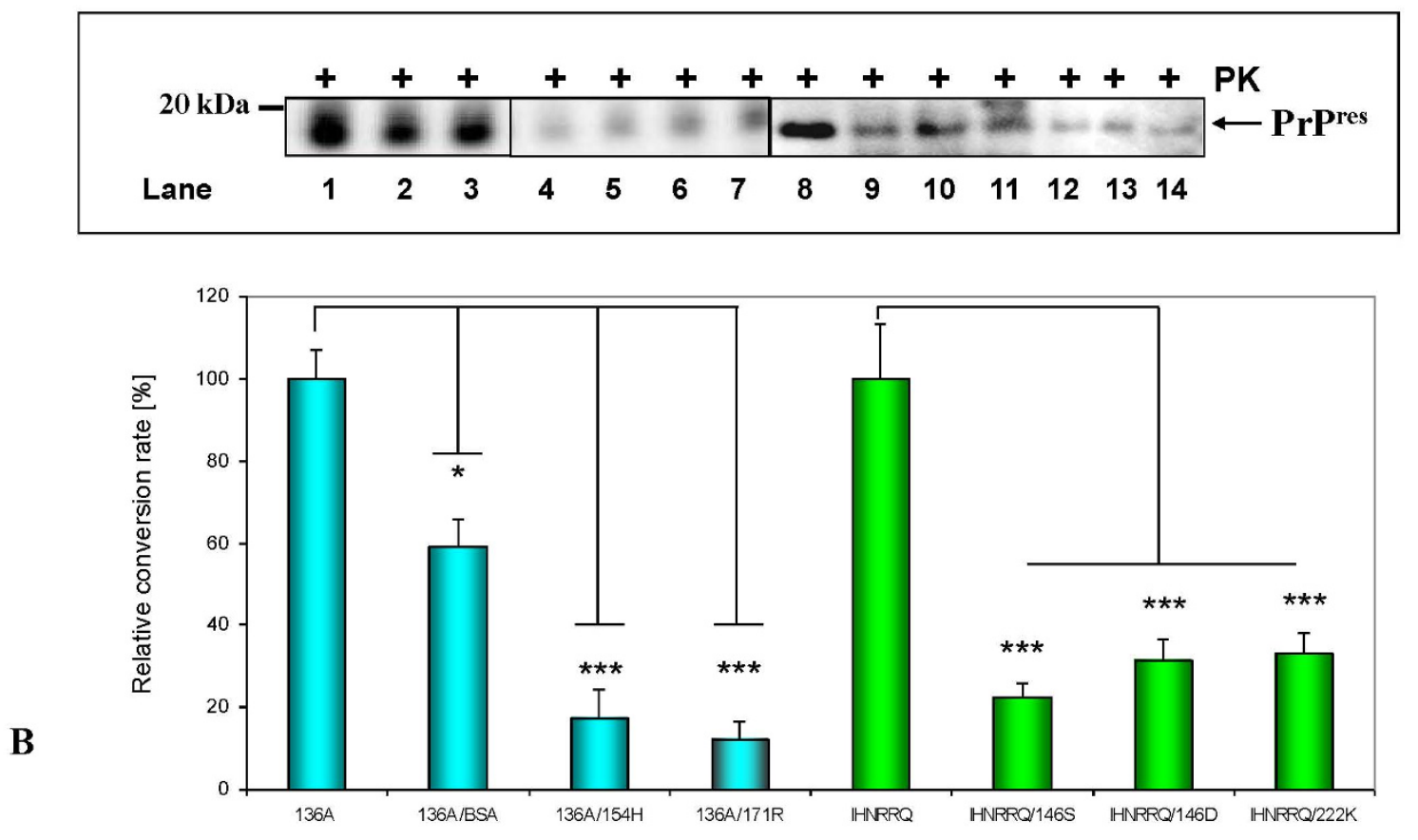

Figure 2 Dominant inhibition of the cell-free conversion by alleles associated with low susceptibility. (A) PrPres fragments generated from 136A (lane 1), a 1:1 mxiture of 136A with BSA (lanes 2-3), a 1:1 mixture of 136A with 171R (lanes 4-5), a 1:1 mixture of 136A with 154H (lanes 6-7). PrP ${ }^{\text {res }}$ fragments derived from IHNRRQ (lane 8), a 1:1 mixture of IHNRRQ with 146S (lanes 9-10), a 1:1 mixture of IHNRRQ with 146D (lanes 11-12) and a 1:1 mixture of IHNRRQ with 222K (lanes 13-14). Detection was carried out using mab P4. Arrow indicates Prpres fragments. (B) Mean relative conversion efficiencies $( \pm$ SEM) for each set of at least four conversion reactions. Relative conversion rates were calculated in relation to the ovine $136 \mathrm{~A}$ reference allele and the caprine IHNRRQ reference allele. The differences were analyzed by unpaired student $t$-test. ${ }^{*}$ : $p<0.05 i^{* *}: p<0.01 ;^{* * *}: p<0.001$. ns: not significant.

interference with the 136A allele and definitely shows an inhibitory effect of $171 \mathrm{R}$ and $154 \mathrm{H}$ alleles over the $136 \mathrm{~A}$ alleles at the protein level.

The same studies were carried out with the caprine PrP variants. The conversion of the wildtype allele IHNRRQ with the mouse-passaged scrapie strain Me7 was confirmed by the formation of a PK-resistant $\mathrm{PrP}^{\text {res }}$ fragment (Figure 1A, lane 6), which harboured a shift in the molecular mass of about 6-7 $\mathrm{kDa}$ in contrast to the untreated control (Figure 1A, lane 5). Amino acid exchanges 142M (Figure 1A, lane 7), R151H (Figure 1A, lane 11) and 211Q (Figure 1A, lane 12) resulted in significantly reduced conversion rates of up to $34.9 \%$ (for $142 \mathrm{M}$ ), 56.9\% (for $\mathrm{R} 151 \mathrm{H}$ ) and $65.4 \%$ (for $211 \mathrm{Q}$ ) in comparison to the IHNRRQ allele alone (Figure 1A, lane 6). Only the 143 allele showed a non significant reduction to $71.1 \%$ (Figure 1A, lane 8). Exchanges at position $146(146 \mathrm{D}, 146 \mathrm{~S})$ and $222(222 \mathrm{~K})$ inhibited a conversion completely (Figure 1A, lanes 9, 10, 13). The relative conversion rates are displayed in Figure 1B. An incomplete proteolysis of full-length PrP by Proteinase
K was observed infrequently (e.g. Figure 1A lane 10), and is a concession to using native buffer conditions and the absence of denaturants like urea or guanidinium hydrochloride.

Possible dominant-negative inhibitions were also analyzed in 1:1 mixtures of the caprine IHNRRQ allele coincubated with the alleles 146S (IHNRRQ/146S), 146D (IHNRRQ/146D) and 222K (IHNRRQ/222K), which are associated with resistance to scrapie. The IHNRRQ conversion was significantly inhibited by $146 \mathrm{~S}$ (Figure 2A, lanes 9-10), 146D (Figure 2A, lanes 11-12) and 222K (Figure 2A, lanes 13-14) with corresponding relative conversion rates of $22.4 \%, 31.4 \%$ and $33.1 \%$ respectively (Figure 2B). Again, the significant reduction of more than $50 \%$ indicates the direct interference of conversion incompetent alleles with the wild-type IHNRRQ allele, leading to dominant-negative inhibition.

\section{Discussion}

Cell-free conversion assays were widely used for the determination of PrP conversion efficiencies and 
evaluation of species barriers in vitro. Here we report the conversion of ovine and caprine polymorphisms in vitro and their association with susceptibility to scrapie in vivo. The used cell-free conversion assay is based on the conversion of recombinant ovine and caprine PrP by a $\mathrm{PrP}^{\mathrm{Sc}}$ seed and involves antibodies, that discriminate between newly converted $\operatorname{PrP}^{\text {res }}$ and the used $\operatorname{PrP}^{\mathrm{Sc}}$ seed via a species specific epitope. We therefore required a scrapie strain which was passaged in another species. We selected the mouse passaged scrapie strain Me7 for our studies, since it was isolated from various classical scrapie cases. Moreover, Me7 retained its biological and physicochemical characteristics during multiple passages in a variety of different species [22,26-28]. Although the conversion of ovine $\mathrm{PrP}$ by mouse passaged strain $\mathrm{Me} 7$ crosses the species barrier, the newly converted recombinant ovine $\operatorname{PrP}^{\text {res }}$ displays the same biochemical characteristics as $\operatorname{PrP}^{\mathrm{Sc}}$ derived from original scrapie. This includes partial PK-resistance, detection by mab $\mathrm{P} 4$ as well as mab L42 and a shift in the molecular mass of the unglycosylated fragment compared to BSE derived fragments (data not shown). The available data suggest that the biological properties of the newly formed $\mathrm{PrP}^{\text {res }}$ molecules are not modified after conversion with mouse adapted strains and that this model represents a suitable system to study ovine and caprine PrP polymorphisms on scrapie susceptibility in vitro.

Molecular structure analysis studies were obtained primarily for ovine $\operatorname{Pr} \mathrm{P}^{\mathrm{C}}$ variants and compared to corresponding convertibility data. The absence of conversion of the $171 \mathrm{R}$ allele was explained by the exchange of glutamine $(\mathrm{Q})$ by the basic residue arginine $(\mathrm{R})$ at position 171 , which interferes with the formation of the extended $\beta$-sheet rich structure during the conversion [29]. In addition, using spectroscopic analysis, it could be demonstrated that the $171 \mathrm{R}$ conformation was less stable than the 136A conformation at physiological temperatures. The low conformational stability inhibited amyloid fibril formation [30]. In the case of the $154 \mathrm{H}$ allele, the exchange of arginine to histidine at position 154 was perturbing the $\alpha$-helix 1 by disrupting the saltbridge between residues D150 and R154 (positions according to human PrP) [31]. Although CD-spectra of different alleles showed similar $\alpha$-helical structures the exchange of one amino acid in the $171 \mathrm{R}$ and $154 \mathrm{H}$ allele caused a reduced thermodynamic and thermal stability in the protein [32].

This is similar to the situation in vivo: expression of the $171 \mathrm{R}$ allele is related to scrapie resistance, and the $154 \mathrm{H}$ allele causes a reduced susceptibility to the disease. In contrast the 136A genotype was found to be highly susceptible, when exposed to natural or experimental classical scrapie [33]. The homozygous genotype $154 \mathrm{H} / 154 \mathrm{H}$ was proposed to be nearly as protective against scrapie as 171R/171R [23]. 154H was also associated with resistance to natural scrapie in Cypriot goats [13]. However, the influence of the $154 \mathrm{H}$ allele on the scrapie susceptibility is ambiguous, which is highlighted by the occurrence of scrapie positive sheep with a homozygous $154 \mathrm{H} / 154 \mathrm{H}$ genotype in a Merinoland sheep flock [34]. Even in sheep, carrying the 171R/171R genotype, which is generally regarded as highly resistant to classical scrapie, two classical scrapie cases were reported [35]. Both alleles, however, are linked to susceptibility for atypical/Nor98 scrapie in affected heterozygous animals [36,37]. Moreover, 171R/171R genotypes [38] and $154 \mathrm{H} / 154 \mathrm{H}$ genotypes [39] are susceptible to BSE after experimental infection. These data indicate that the influence of both alleles to scrapie susceptibility displays a complex interplay with different TSE strains and probably depends on additional genetic and epidemiological risk factors.

Co-incubation of the $171 \mathrm{R}$ and $154 \mathrm{H}$ variant with the $136 \mathrm{~A}$ allele, termed $136 \mathrm{~A} / 171 \mathrm{R}$ and $136 \mathrm{~A} / 154 \mathrm{H}$, resulted in a significantly reduced conversion rate in contrast to the single 136A genotype. A similar effect has been observed with hamster allele 172R, which inhibits the conversion of wild type hamster PrP in vitro [40]. According to the stone fence model [41], the loss of conversion efficiency can be explained by the incorporation of conversion incompetent $171 \mathrm{R}$ or $154 \mathrm{H}$ molecules into the 136A aggregates, which delay or block fibril elongation. The interference of alleles linked to high susceptibility with alleles linked to low susceptibility in vitro is in good accordance with the situation in vivo. Sheep carrying the $136 \mathrm{~A} / 154 \mathrm{H}$ or the $136 \mathrm{~A} /$ $171 \mathrm{R}$ allele show a reduced susceptibility to scrapie compared to the 136A/136A allele [2]. The dominantnegative inhibition works therefore on protein level and is probably not caused by preferential expression of the susceptible alleles. This could be demonstrated by assessment of $\operatorname{PrP}$ transcripts from heterozygous 136A/ $171 \mathrm{R}$ sheep and the confirmation of equal use of both alleles [42]. These results also argument also against the existence of the proposed factor X [43]. However, the age related increase of $136 \mathrm{~A} / 154 \mathrm{H}$ scrapie cases [2] highlights the erratic role of $154 \mathrm{H}$ polymorphism and suggests the involvement of additional factors.

Due to a limited number of goats, which harbour disease associated polymorphisms, a significant correlation of specific polymorphisms to susceptibility is difficult to obtain in vivo. The $142 \mathrm{M}$ polymorphism is found with a low frequency in the goat population, but experimental infection of $142 \mathrm{M}$ goats with scrapie and BSE strains showed an increased incubation period [10]. This is in agreement with the reduced convertibility of the recombinant $142 \mathrm{M}$ allele in vitro. A similar correlation was found at codon 143. Studies on the relative scrapie 
incidence in goats carrying different $\operatorname{PrP}$ genotpes in Greek goat herds revealed a moderately protective effect of the 143R polymorphism [11]. We have observed a similar effect in the here reported in vitro studies. A similar protective effect may also exist for the R151H polymorphism in Cypriot goats [13,44]. Another polymorphism (211Q) in French goats is also suspected to reduce the scrapie susceptibility [12]. This is consistent with our findings, in which the exchange of arginine (R) to glutamine $(\mathrm{Q})$ at position 211 in recombinant $\operatorname{PrP}$ caused a reduced conversion rate.

Two novel polymorphisms at position 146 (146D and 146S) were found in scrapie-negative animals in Cypriot goat herds [44]. The protective effects of exchanges from asparagine $(\mathrm{N})$ to aspartic acid (D) or serine $(\mathrm{S})$ were confirmed in the cell-free conversion by the complete absence of $\mathrm{PrP}^{\text {res }}$ fragments of the respective $\operatorname{PrP}^{\mathrm{C}}$ variant. The inhibitory potential of these variants was confirmed by dominant-negative effects in vitro, where co-incubation with the susceptible IHNRRQ allele caused a significant decrease in the conversion rate for both the IHNRRQ/146D and the IHNRRQ/146S variants.

An exchange from glutamine $(\mathrm{Q})$ to lysine $(\mathrm{K})$ at position $222(222 \mathrm{~K})$ revealed another protective polymorphism in goats. Looking at scrapie outbreaks in Italian goats, this polymorphism was found only in healthy animals [14]. The conversion of recombinant $222 \mathrm{~K}$ allele was completely abolished in vitro and significantly reduced the conversion rate of the susceptible IHNRRQ allele during co-incubation. Similar effects were found in human PrP, where the E219K allele was reported to protect against Creutzfeldt-Jakob-Disease [45]. In addition, the influence of the Q218K variant of the mouse prion protein was analysed in vitro and found to significantly reduce aggregation kinetic and induce a dominant-negative effect on murine wildtype prion protein [46]. This way, insertion of an additional positive charge at position 222 of the caprine prion protein is assumed to interfere with $\operatorname{PrP}^{\mathrm{C}} / \mathrm{PrP}^{\mathrm{Sc}}$ interaction.

In summary, the here reported in vitro conversion studies support the association of specific ovine and caprine PRNP polymorphisms with a reduced classical scrapie susceptibilities in vivo. Moreover we could demonstrate an interference of susceptible PrP alleles by co-incubation with inhibitory alleles in vitro, which apparently corresponds to prolonged incubation times of heterozygous animals in vivo.

\section{Acknowledgements}

We gratefully acknowledge Birke Kalb, Daniel Balkema and Baerbel Hammerschmidt for their excellent technical support. Elizabeth Ortega Soto participated in the Government scholarship program offered by Consejo
Nacional de Ciencia y Tecnologia (CONACYT), Mexico, in cooperation with DAAD (Deutscher Akademischer Austausch Dienst), Germany.

\section{Author details}

${ }^{1}$ Institute for Novel and Emerging Infectious Diseases at the FriedrichLoeffler-Institut, Federal Research Institute for Animal Health, D-17493 Greifswald-Insel Riems, Germany. ${ }^{2}$ Institute of Molecular Biology at the Friedrich-Loeffler-Institut, Federal Research Institute for Animal Health, D17493 Greifswald-Insel Riems, Germany.

\section{Authors' contributions}

ME and EOS carried out the experimental work and performed the statistical analysis. TCM reviewed the data interpretation. MHG and ME designed this study, interpreted the results and wrote the manuscript. All authors read and approved the final manuscript.

\section{Competing interests}

The authors declare that they have no competing interests.

Received: 23 August 2010 Accepted: 15 February 2011

Published: 15 February 2011

\section{References}

1. Baylis M, Goldmann W: The genetics of scrapie in sheep and goats. Curr Mol Med 2004, 4:385-396.

2. Baylis M, Chihota C, Stevenson E, Goldmann W, Smith A, Sivam K Tongue S, Gravenor MB: Risk of scrapie in British sheep of different prion protein genotype. J Gen Virol 2004, 85:2735-2740.

3. Benestad SL, Arsac JN, Goldmann W, Nöremark M: Atypical/Nor98 scrapie: properties of the agent, genetics, and epidemiology. Vet Res 2008, 39:19.

4. Colussi S, Vaccari G, Maurella C, Bona C, Lorenzetti R, Troiano P, Casalinuovo F, Di Sarno A, Maniaci MG, Zuccon F, Nonno R, Casalone C, Mazza M, Ru G, Caramelli M, Agrimi U, Acutis PL: Histidine at codon 154 of the prion protein gene is a risk factor for Nor98 scrapie in goats. $J$ Gen Virol 2008, 89:3173-3176.

5. González L, Martin S, Houston FE, Hunter N, Reid HW, Bellworthy SJ, Jeffrey M: Phenotype of disease-associated PrP accumulation in the brain of bovine spongiform encephalopathy experimentally infected sheep. J Gen Virol 2005, 86:827-38.

6. Bossers A, Schreuder BE, Muileman $I H$, Belt PB, Smits MA: PrP genotype contributes to determining survival times of sheep with natural scrapie. J Gen Virol 1996, 77:2669-2673.

7. Hunter N: PrP genetics in sheep and the applications for scrapie and BSE. Trends Microbiol 1997, 5:331-334.

8. Dawson $M$, Hoinville $L$, Hosie BD, Hunter $N$ : Guidance on the use of PrP genotyping as an aid to the control of clinical scrapie. Scrapie Information Group. Vet Rec 1998, 142:623-625.

9. Vaccari $G$, Panagiotidis CH, Acin C, Peletto S, Barillet F, Acutis P, Bossers A, Langeveld J, Van Keulen L, Sklaviadis T, Badiola JJ, Andreéoletti O, Groschup MH, Agrimi U, Foster J, Goldmann W: State-of-the-art review of goat TSE in the European Union, with special emphasis on PRNP genetics and epidemiology. Vet Res 2009, 40:48.

10. Goldmann W, Martin T, Foster J, Hughes S, Smith G, Hughes K, Dawson M, Hunter N: Novel polymorphisms in the caprine PrP gene: a codon 142 mutation associated with scrapie incubation period. J Gen Virol 1996, 77:2885-2891.

11. Billinis $C$, Panagiotidis $\mathrm{CH}$, Psychas $\mathrm{V}$, Argyroudis S, Nicolaou A, Leontides $\mathrm{S}$, Papadopoulos O, Sklaviadis T: Prion protein gene polymorphisms in natural goat scrapie. J Gen Virol 2002, 83:713-721.

12. Barillet $F$, Mariat $D$, Amigues $Y$, Faugeras $R$, Caillat $H$, Moazami-Goudarzi $K$, Rupp R, Babilliot JM, Lacroux C, Lugan S, Schelcher F, Chartier C, Corbière F, Andréoletti $\mathrm{O}$, Perrin-Chauvineau $\mathrm{C}$ : Identification of seven haplotypes of the caprine PrP gene at codons 127, 142, 154, 211, 222 and 240 in French Alpine and Saanen breeds and their association with classical scrapie. J Gen Virol 2009, 90:769-776.

13. Papasavva-Stylianou P, Wind $O$, Saunders G, Mavrikiou P, Toumazos $P$ Kakoyiannis C: PrP gene polymorphisms in Cyprus goats and their association with resistance or susceptibility to natural scrapie. Vet J 2010.

14. Acutis PL, Bossers A, Priem J, Riina MV, Peletto S, Mazza M, Casalone C, Forloni G, Ru G, Caramelli M: Identification of prion protein gene 
polymorphisms in goats from Italian scrapie outbreaks. J Gen Virol 2006 87:1029-1033.

15. Bessen RA, Kocisko DA, Raymond GJ, Nandan S, Lansbury PT, Caughey B: Non-genetic propagation of strain-specific properties of scrapie prion potein. Nature 1995, 375:698-700

16. Bossers A, Rigter A, de Vries R, Smits MA: In vitro conversion of normal prion protein into pathologic isoforms. Clin Lab Med 2003, 23:227-247.

17. Kocisko DA, Come JH, Priola SA, Chesebro B, Raymond GJ, Lansbury PT, Caughey B: Cell-free formation of protease-resistant prion protein. Nature 1994, 370:471-474

18. Raymond GJ, Bossers A, Raymond LD, O'Rourke Kl, McHolland LE, Braynt PK III, Miller MW, Williams ES, Smits M, Caughey B: Evidence of a molecular barrier limiting susceptibility of humans, cattle and sheep to chronic wasting disease. EMBO J 2000, 19:4425-4430.

19. Eiden M, Palm GJ, Hinrichs W, Matthey U, Zahn R, Groschup MH: Synergistic and strain-specific effects of bovine spongiform encephalopathy and scrapie prions in the cell-free conversion of recombinant prion protein. J Gen Virol 2006, 87:3753-3761.

20. Bocharova OV, Breydo L, Parfenov AS, Salnikov W, Baskakov IV: In vitro conversion of full-length mammalian prion protein produces amyloid form with physical properties of PrP ${ }^{\text {Sc }}$. J Mol Biol 2005, 346:645-659.

21. Eiden M, Buschmann A, Kupfer L, Groschup MH: Synthetic prions. J Vet Med B Infect Dis Vet Public Health 2006, 53:251-256.

22. Bruce ME, Boyle A, Cousens S, McConnell I, Foster J, Goldmann W, Fraser H: Strain characterization of natural sheep scrapie and comparison with BSE. J Gen Virol 2002, 83:695-704.

23. Junghans F, Teufel B, Buschmann A, Steng G, Groschup MH: Genotyping of German sheep with respect to scrapie susceptibility. Vet Rec 1998, 143:340-341.

24. Zahn R, von Schroetter C, Wüthrich K: Human prion proteins expressed in Escherichia coli and purified by high-affinity column refolding. FEBS Lett 1997, 417:400-404

25. Harmeyer S, Pfaff E, Groschup MH: Synthetic peptide vaccines yield monoclonal antibodies to cellular and pathological prion proteins of ruminants. J Gen Virol 1998, 79:937-945.

26. Bruce ME, Fraser H: Scrapie strain variation and its implications. Curr Top Microbiol Immunol 1991, 172:125-138.

27. Kuczius T, Haist I, Groschup MH: Molecular analysis of bovine spongiform encephalopathy and scrapie strain variation. J Infect Dis 1998, 178:693-699.

28. Kuczius T, Groschup MH: Differences in proteinase $\mathrm{K}$ resistance and neuronal deposition of abnormal prion proteins characterize bovine spongiform encephalopathy (BSE) and scrapie strains. Mol Med 1999, 5:406-418

29. Thackray AM, Yang S, Wong E, Fitzmaurice TJ, Moragan-Warren RJ, Bujdoso R: Conformational variation between allelic variants of cellsurface ovine prion protein. Biochem J 2004, 381:221-229.

30. Paludi D, Thellung S, Chiovitti K, Corsaro A, Villa V, Russo C, lanieri A Bertsch U, Kretzschmar HA, Aceto A, Florio T: Different structural stability and toxicity of $\operatorname{PrP}(\mathrm{ARR})$ and $\operatorname{PrP}(\mathrm{ARQ})$ sheep prion protein variants. I Neurochem 2007, 103:2291-300

31. Megy S, Bertho G, Kozin SA, Debey P, Hui Bon Hoa G, Girault JP: Possible role of region 152-1256 in the structural duality of a peptide fragment from sheep prion protein. Protein Sci 2008, 13:3151-3160.

32. Fitzmaurice TJ, Burke DF, Hopkins L, Yang S, Yu S, Sy MS, Thackray AM, Bujdoso R: The stability and aggregation of ovine prion protein associated with classical and atypical scrapie correlates with the ease of unwinding of helix-2. Biochem J 2008, 409:367-375.

33. Belt PB, Muileman IH, Schreuder BE, Bos-de Ruijter J, Gielkens AL, Smits MA: Identification of five allelic variants of the sheep PrP gene and their association with natural scrapie. J Gen Virol 1995, 76:509-517.

34. Luhken G, Buschmann A, Groschup MH, Erhardt G: Prion protein allele A136 H154Q171 is associated with high susceptibility to scrapie in purebred and crossbred German Merinoland sheep. Arch Virol 2004, 149:1571-1580.

35. Groschup MH, Lacroux C, Buschmann A, Lühken G, Mathey J, Eiden M, Lugan S, Hoffmann C, Espinosa JC, Baron T, Torres JM, Erhardt G, Andreoletti O: Classic scrapie in sheep with the ARR/ARR prion genotype in Germany and France. Emerg Infect Dis 2007, 13:1201-1207.

36. Buschmann A, Biacabe AG, Ziegler U, Bencsik A, Madec JY, Erhardt G, Luhken G, Baron T, Groschup MH: Atypical scrapie cases in Germany and
France are identified by discrepant reaction patterns in BSE rapid tests. $J$ Virol Methods 2004, 117:27-36.

37. Saunders GC, Cawthraw S, Mountjoy SJ, Hope J, Windl O: PrP genotypes of atypical scrapie cases in Great Britain. J Gen Virol 2006, 87:3141-3149.

38. Andréoletti $\mathrm{O}$, Morel $\mathrm{N}$, Lacroux $\mathrm{C}$, Rouillon $\mathrm{V}$, Barc $\mathrm{C}$, Tabouret $\mathrm{G}$, Sarradin $P$, Berthon $P$, Bernardet $P$, Mathey J, Lugan $S$, Costes $P$, Corbière F, Espinosa JC, Torres JM, Grassi J, Schelcher F, Lantier F: Bovine spongiform encephalopathy agent in spleen from an ARR/ARR orally exposed sheep. J Gen Virol 2006, 87:1043-1046.

39. Foster JD, Parnham D, Chong A, Goldmann W, Hunter N: Clinical signs, histopathology and genetics of experimental transmission of BSE and natural scrapie to sheep and goats. Vet Rec 2001, 148:165-171.

40. Geoghegan JC, Miller MB, Kwak AH, Harris BT, Supattapone S: Transdominant inhibition of prion propagation in vitro is not mediated by an accessory cofactor. PLoS Pathog 2009, 5:e1000535.

41. Kobayashi A, Hizume M, Teruya K, Mohri S, Kitamoto T: Heterozygous inhibition in prion infection: the stone fence model. Prion 2009, 3:27-30

42. Caplazi PA, O'Rourke Kl, Baszler TV: Resistance to scrapie in PrP ARR/ARQ heterozygous sheep is not caused by preferential allelic use. J Clin Pathol 2004, 57:647-650.

43. Kaneko K, Zulianello L, Scott M, Cooper CM, Wallace AC, James TL, Cohen FE, Prusiner S: Evidence for protein $\mathrm{X}$ to a discontinuous epitope on the cellular prion protein during scrapie prion propagation. Proc Natl Acad Sci USA 1997, 94:100069-100074.

44. Papasavva-Stylianou P, Kleanthous M, Toumazos P, Mavrikiou P, Loucaides P: Novel polymorphisms at codons 146 and 151 in the prion protein gene of Cyprus goats, and their association with natural scrapie. Vet J 2007 173:459-62.

45. Shibyua S, Higuchi J, Shin RW, Tateishi J, Kitamoto T: Codon 219 Lys allele of PRNP is not found in sporadic Creutzfeldt-Jakob disease. Ann Neurol $1998,43: 826-828$.

46. Lee Cl, Qingyuan Y, Perrier V, Baskakov IV: The dominant-negative effect of the Q218K variant of the prion protein does not require protein X. Prot Sci 2007, 16:1-8.

doi:10.1186/1297-9716-42-30

Cite this article as: Eiden et al:: Effects of polymorphisms in ovine and caprine prion protein alleles on cell-free conversion. Veterinary Research $201142: 30$

\section{Submit your next manuscript to BioMed Central and take full advantage of:}

- Convenient online submission

- Thorough peer review

- No space constraints or color figure charges

- Immediate publication on acceptance

- Inclusion in PubMed, CAS, Scopus and Google Scholar

- Research which is freely available for redistribution

Submit your manuscript at www.biomedcentral.com/submit
C Biomed Central 